\title{
EL PODER Y EL PLACER DEL LÓGOS
}

Sobre Ivana S. Chialva et al. Encomio de Helena - Gorgias. Santa Fe: Ediciones UNL, 2013. 100 pp.

Marcela Coria

UNR

Gorgias de Leontinos (ca. 485-380 a.C.), es una figura central en el movimiento sofístico, que se destacó por las innovaciones que introdujo en la técnica de la oratoria y por el uso de numerosas y variadas figuras poéticas. Este trabajo de Ivana Chialva, Micaela Ma. Bonacossa, Ma. Nidia Casís y Ma. Luz Omar, revisado por Francesca Mestre, tiene el propósito de ofrecer una nueva traducción anotada de uno de los ejemplos más importantes del arte retórico de Gorgias: el Encomio de Helena, pero también de "elucidar la productividad de la léxis gorgiana como necesaria base formal de una reflexión en torno al lógos y a sus alcances" (p. 17), objetivo que se logra en el Estudio Preliminar.

Este Estudio está formado por ocho apartados: "El sofista de los testimonios", donde se exponen los testimonios antiguos sobre la vida de Gorgias y la valoración de su obra por parte de filósofos y representantes de la segunda sofística; "Obras del sofista", donde se explica brevemente el contenido de las tres obras consideradas de su autoría (Sobre el no ser, Defensa de Palamedes y Encomio de Helena) y una breve noticia sobre declamaciones públicas del autor mencionadas por Flavio Filóstrato y que no han llegado a nuestros días; "El cosmos verbal: las funciones de las figuras gorgianas (schémata 
gorgieia)", "El uso argumentativo de los schémata gorgieia" y "La ambivalencia del lógos-phármakon", en los cuales se exponen las principales características del discurso gorgiano, sus procedimientos, las figuras más recurrentes en su obra (ejemplificadas) y sus implicancias retóricas; "Acerca de nuestra traducción", donde las autoras aclaran criterios importantes en relación con la traducción que ofrecen; "Notas al Estudio Preliminar" y "Acerca de la edición del texto griego", apartado en el que se registran las divergencias con respecto a la edición utilizada (Diels-Kranz).

A este Estudio Preliminar sigue el texto griego del Encomio de Helena y su traducción en página opuesta, las notas al texto griego, las notas a la traducción y la bibliografía. La traducción es ágil y correcta, realizada en un español elegante, y las notas, abundantes y esclarecedoras. La bibliografía utilizada incluye obras ya clásicas sobre el autor y el Encomio pero también artículos y publicaciones actuales de reconocidos eruditos.

Esta obra, breve pero rigurosa y muy útil para quien se inicia en el estudio de Gorgias y de la sofística, se destaca por su didactismo: los conceptos técnicos son explicados con definiciones y ejemplos muy claros, y se remite de manera constante a las fuentes antiguas y a la bibliografía crítica específica para que el lector pueda ampliar sus conocimientos sobre los temas abordados. Recomendamos, por lo tanto, la lectura de esta obra, amena, bien documentada y ciertamente meritoria. 